\title{
部品内蔵基板向けはんだペースト技術
}

\author{
日渡 逸人*
}

\section{Solder Paste Technologies for Embedded Substrate}

Hayato HIWATASHI*

*千住金属工業株式会社ハンダテクニカルセンター（† 120-8555 東京都足立区千住橋戸町 23 番地）

* Solder Technical Center, Senju Metal Industry CO., LTD. (23, Senju Hashido-cho Adachi-ku Tokyo 120-8555)

\section{1.はじめに}

モバイル機器の高機能化を促進させるために実装基板の 高密度化は必然的なものとなっており, 中でも最近, 情報 媒体で目にする機会が増えてきたウエアラブル端末におい ては，デザイン性の観点から極めて限られたスペースにセ ンサなどのモジュール部品を実装, またはフレキシブル基 板などで繋げた実装基板を組み込む必要性から，今まで以 上の高密度化が求められる。このような省スペース化の要 求や処理速度向上の目的から実装部品を基板内へ埋め込む 技術が生まれ，モバイル機器に採用されるようになってき ている。部品内蔵基板が市場でさらに受け入れられるため には機器性能だけでなくコストも非常に重視されるため, 性能向上とコストダウンを両立させる技術開発が必要とな る。この市場の要求にはんだ付け技術も追従すべく, 微細 ピッチへの対応やコスト低減の実現など, さまざまな角度 から材料開発が進められている。部品内蔵基板では通常の 基板製造工程に加え部品実装, または部品埋め込みが必要 となるため, これにより工程が増えコスト高は免れない。 このように工程が増える中でいかにして品質を確保しなが ら工数を抑制するかがカギになると思われるが，はんだ メーカの立場から, 上記工程増を抑制できる可能性を持つ はんだぺースト技術について紹介する。

\section{2. 基板に埋め込まれるはんだ材料の課題}

具体的な材料技術の紹介の前に部品内蔵基板におけるは んだ材料の課題を挙げてみたい。部品内蔵基板の製造プロ セスは(1)既存部品内蔵, (2)薄型部品内蔵, (3)膜素子形成の 3 種類がある ${ }^{1)}$ 。はんだペーストが使用されるケースは上 記(1)の場合であり, 通常の表面実装と同様の工程（はんだ 印刷, 部品実装, リフロー）となるが, 次工程で, はんだ 付けされた部品全体を樹脂で埋めるため, 部品およびはん だと樹脂との密着性が必要となる。

一般的なはんだペーストの場合リフロー後にフラックス 残椬が残り, このフラックス残椬が埋め込み樹脂と密着性
が悪い場合には，フラックス残椬の洗浄工程が必要となっ てしまうため, フラックス残椬には樹脂との密着性が求め られる。部品が埋め込まれた基板は，その最表面にさらに 通常の部品が実装され，またその完成品がモジュールの場 合では，マザーボードに実装され再度リフロー（2 次実装） される。この再度リフローされる温度が埋め达み時に使用 したはんだの融点を超えるとはんだは再溶融し，設計に よって部品のズレや場合によっては溶融したはんだが電極 間を短絡させるリスクがある。これら 2 点の課題をそれぞ れ解決し，かつ工程増を抑制できる可能性を持つ技術を以 下に紹介する。

\section{3. 基板樹脂との密着性を向上させるフラックス技術}

接合後のフラックス残椬が埋め込み樹脂との良好な密着 性を実現し，洗浄工程の省略を実現する技術を紹介する。 本技術は埋め込み樹脂と相溶性の高い熱硬化性樹脂をぺー スト用フラックスに添加することで埋め込み樹脂との高い 密着性を実現しており, リフロー後に樹脂が硬化すること から，はんだ付け後のフラックス残椬が接合部をプロテク トする機能も有する。硬化したフラックス残椬がはんだ接 合部や基板, 部品に密着し，はんだ接合部をプロテクトす ることで優れた接合強度を長期にわたり維持させることを 実現している（図 1 参照）。

一般的な SAC 系はんだペーストと接合部にプロテクト機 能を持たせたはんだペースト（以下，JPP と略す）による $\mathrm{TCT}$ 評価（冷熱サイクル試験， $-55^{\circ} \mathrm{C} \Leftrightarrow+125^{\circ} \mathrm{C}, 30$ 分保

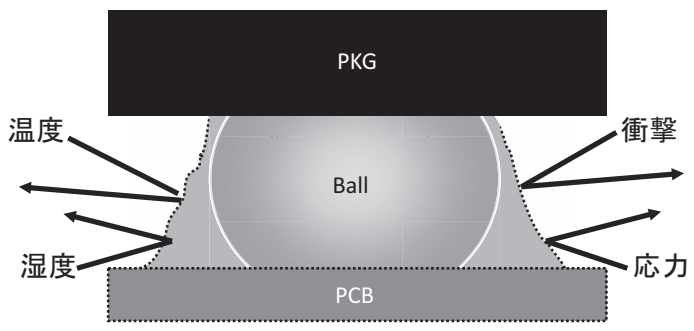

図 1.フラックス残渣が接合部を保護 
持，1005 チップ部品）を実施した（図 2 参照）。JPP は一般 的なはんだペーストと比ベフラックス残渣で接合部をプロ テクトする機能により，初期から 1,000 サイクル後まで高 い強度を維持している。JPP のフラックス残椬に良好なプ ロテクト機能を発揮させるためには, 樹脂が十分に硬化し て接合部にしっかり密着することが必要となる。この樹脂 の硬化度合いは熱履歴により変化することから, 基板と JPP のフラックス残渣との密着強度がリフロープロファイルで どの程度変化するかを検証した。試験方法ははんだの接合 強度の影響を排除し純粋にフラックス残椬の密着強度だけ を評価するため, 基板のレジスト表面にはんだペーストを 印刷 $\rightarrow$ 加熱（図 3-1，2参照）し，せん断強度を測定し た。強度測定の結果, 破壊は基板とフラックス残渣の界面

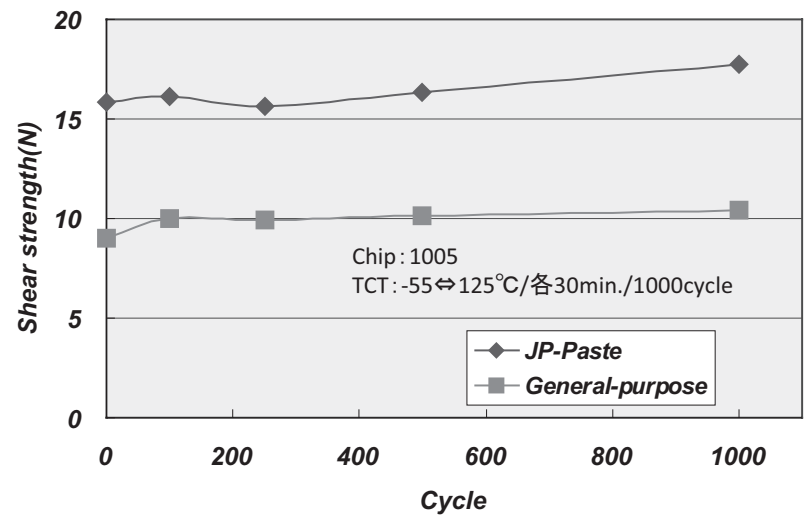

図 2. シェア強度比較
で発生している（図 3-3，4 参照）。

加熱温度が高く，また時間が長い条件ほど高い密着強度 を示している (図 3-5 参照)。この結果は SAC305 組成 $(\mathrm{Sn}-3.0 \mathrm{Ag}-0.5 \mathrm{Cu})$ を念頭に置いたリフロープロファイルで の結果であるが，融点の低い $\mathrm{SnBi}$ 共晶系はんだにおいても 専用フラックスと組み合わせることで同様の挙動が得られ る。

この技術を使ったはんだペーストは，はんだ接合部をプ ロテクトするだけでなく埋め込み樹脂との密着性が高いこ とから洗浄も不要となり, コス卜低減を実現可能な接合材 料としてパワーモジュール分野への採用も進んでいる。

\section{4. フラックス残渣の残らないはんだペースト技術}

通常はんだペーストはリフロー後に接合部にフラックス 残渣が残留する。この残渣が残らなければ樹脂との密着性 に関する懸念もなくなり,さらに洗浄工程も不要となるこ とからコスト低減に繋がる。フラックス残椬を無くすため にはこれまでのフラックス開発の考えとは違った発想が必 要となる。

図 4 に一般的なはんだペースト用フラックス材料構成の 概略を示す。これら材料中，主にロジンとチキソ剤がリフ ロー後にフラックス残渣として残留するため, フラックス 残渣の残留を無くすためには，この 2 種類の材料を使用し ない，もしくはリフロー中に全て揮発させる必要がある。 はんだペースト中でこれら 2 種類の材料が果たす役割を簡 単に説明すると，ロジンはそれ自体が還元作用を持つた

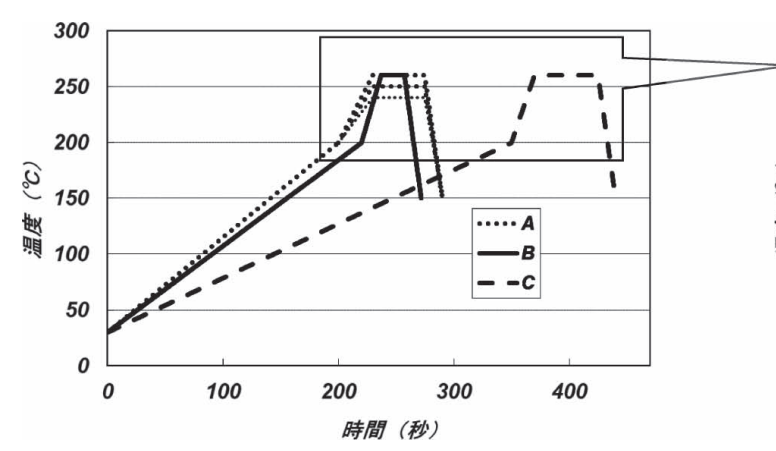

図 3-1. 温度プロファイル

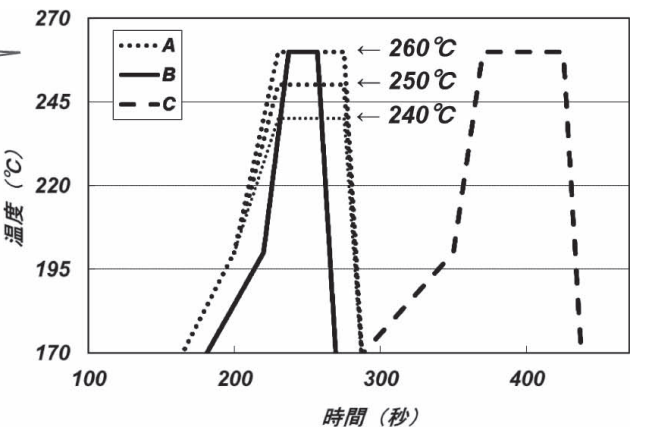

図 3-2. 温度プロファイル（ピーク領域）

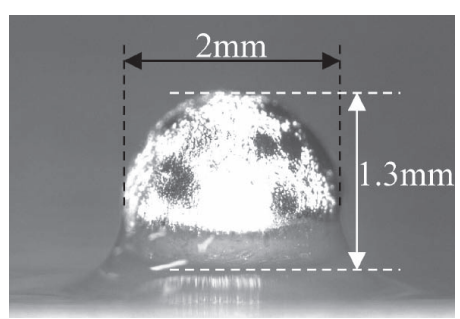

図 3-3. 試験片外観

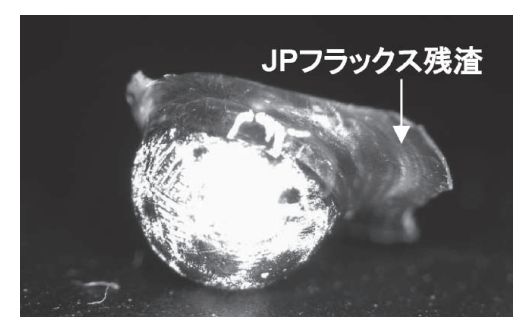

図 3-4. 強度測定後試験片外観

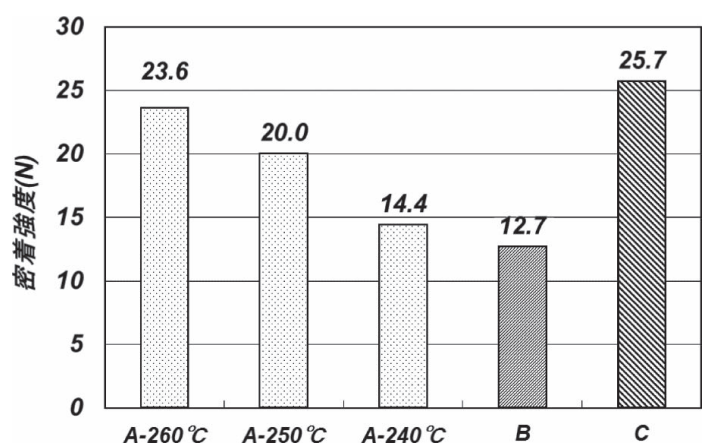

図 3-5. 基板との密着強度（シェア） 


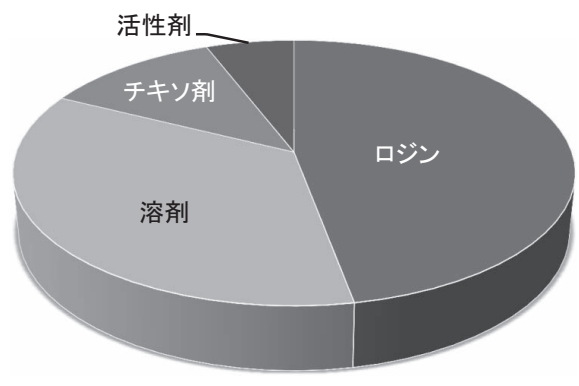

図 4. フラックス材料構成

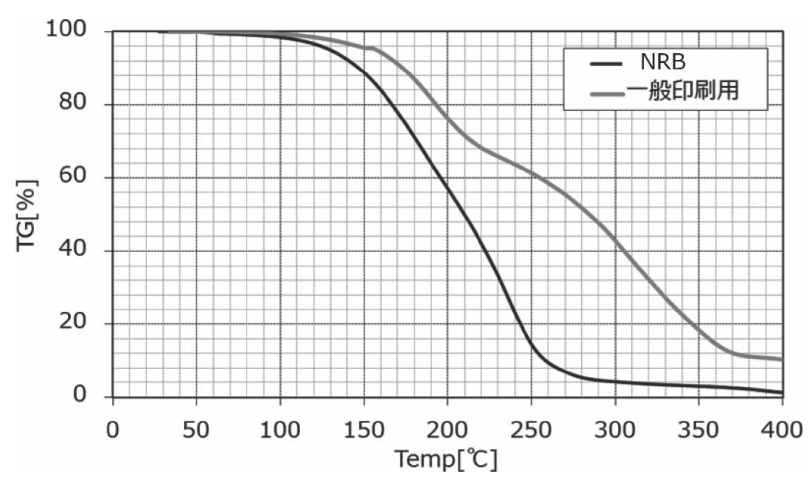

図 5. フラックスの TG 測定結果

め, はんだや電極表面の酸化膜除去作用と再酸化抑制作用 を持つ。また，チキソ郕ははんだペーストの粘性を保ち形 状を維持する, いずれもはんだペーストの性能を司る重要 な材料である。そもそもこれら材料はリフロー中に存在す ることでその機能を発揮しており, フラックス残渣を残留 させない目的と相反するため, これらを両立することは容 易ではない。

しかしながら技術の進歩は素晴らしいもので, 使用条件 は制限されるもののリフロー後フラックス残渣として残留 しないはんだペーストの開発に成功している。一般的なは んだペーストと残渣が残留しないはんだペースト（以下， $\mathrm{NRB}$ と略す）の各ペースト用フラックスの TG（熱重量分 析）測定の比較デー夕（図 5 参照) では, 一般的なペース 卜用フラックスは $400^{\circ} \mathrm{C}$ の高温でも重量はゼロにならな い。これは残椬として基板上に残留することを意味する。 これに対しNRBでは，はんだ融点近傍においてゼロに近 い值を示しており，フラックスが加熱中に揮発して残渣と してほとんど残留しないことを示している。

NRB を用いて 0603 チップを酸素濃度 1,500 ppm 以下で 実装した後の基板 SEM 像を図 6 に示す。この SEM 像か ら, フラックス残渣が残留することなく, 良好なはんだ付 け性が得られていることが見て取れる。この技術は部品内 蔵分野だけでなく, パワーモジュールの様なフラックス残 椬洗浄が必要とされている分野でも注目されており, 既に 一部実用化が開始されている。

また，工法との組み合わせで NRB の特性をさらに引き 立たせる技術も開発されており, 真空リフロー炉を使用す

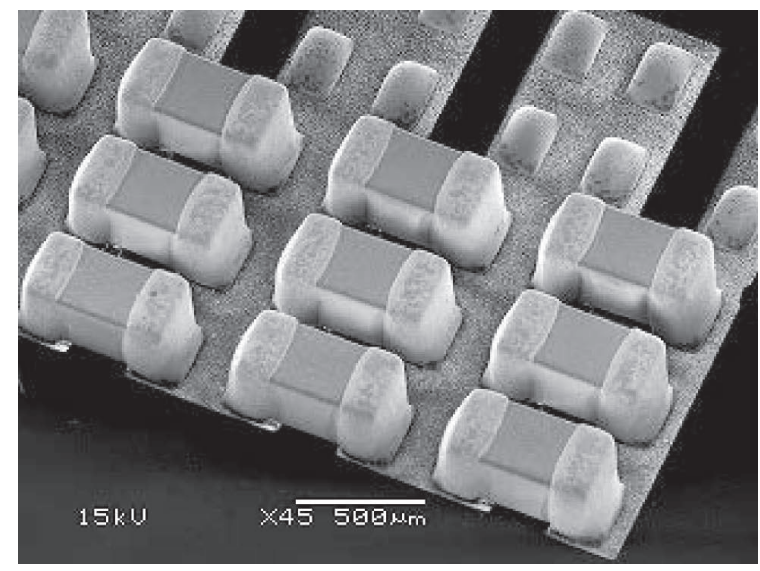

図 6. リフロー後の SEM 像

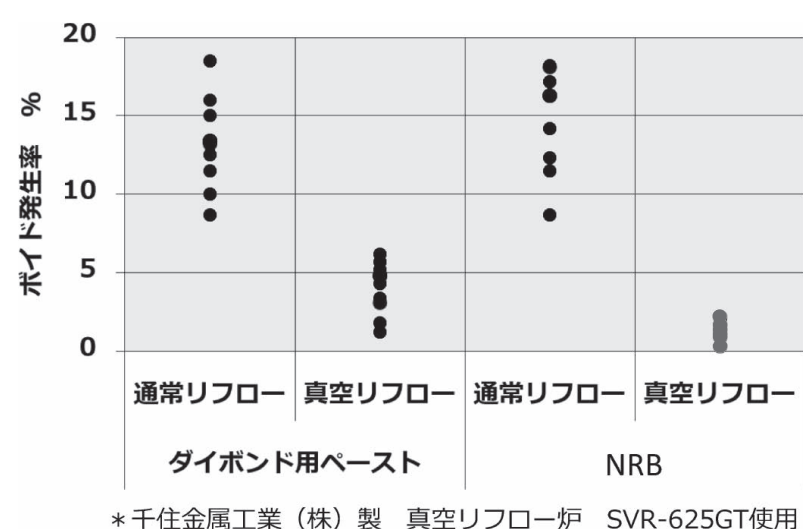

図 7. ボイド発生率測定結果

ることにより，残渣のみならずボイドもゼロに近い值を実 現している（図 7 参照：エックス線透過装置にてはんだ付 け部を観察し, ボイド面積/ランド面積 = ボイド発生率 $(\%)$ として算出)。

\section{5. 再リフロー時にも部品保持可能な接合材料技術}

部品内蔵基板は二次実装時に再加熱されるため高融点の はんだが求められる。

数種類の金属を組み合わせることである程度の高融点化 は可能だが，安価で $\mathrm{Pb}$ を含有しないといった制約下にお いては, 従来の $\mathrm{Sn}-\mathrm{Pb}$ 高融点はんだ $\left(300^{\circ} \mathrm{C}\right.$ 近傍 $)$ と同様 の融点を持つ実使用可能なはんだは見受けられない。これ は Pb フリーはんだの主金属となる $\mathrm{Sn}$ の融点が足かせとな り, 比較的融点の高い組成でも一般的に知られている組成 では $\mathrm{Sn}-10 \mathrm{Sb}$ (固相： $245^{\circ} \mathrm{C}$ ）程度である。

そこで, SAC305 の様な Sn を主体とするはんだ粉末と高 融点金属粉末を混ぜ合わせることで高融点金属と Sn の反 応により金属間化合物（例えば $\mathrm{Cu}_{6} \mathrm{Sn}_{5}$ ) をはんだ中に網目 状に生成させ，再加熱時においても接合された部品を保持 する技術が既に開発されている (図 8 参照 $)^{2)}$ 。

このはんだ粉末と高融点金属粉末からなるはんだペース

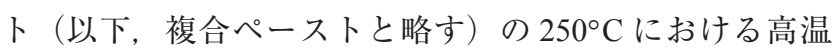




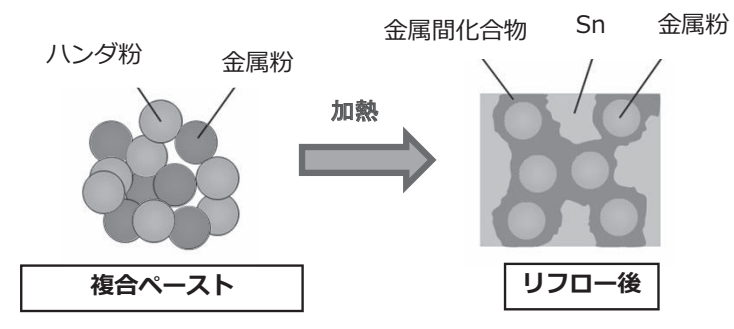

図 8. 高温化プロセス概念図

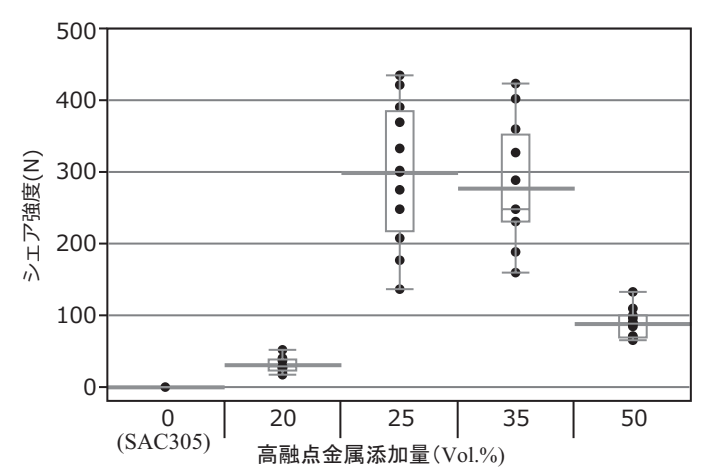

図 9. 高温シェア測定結果

シェア強度測定結果を実施した (図 9 参照)。SAC305 は本 試験時の $250^{\circ} \mathrm{C} て ゙ は$ 融点を超えているため部品との接合強 度は無いに等しい。対して複合ペーストは接合部内に網目 状に高融点金属間化合物が生成していることから， $250^{\circ} \mathrm{C}$ においても一定の強度を有する。また, 高融点金属の添加 量によって強度は異なり, 最適な添加量が存在することを 示唆している。以上のことから高温 $\mathrm{Pb}$ フリーはんだとし て有望な技術であるが，金属間化合物をはんだ中に生成し ていることから, セルフアライメント性の確保（微小部品 実装ではリペアが困難であり，七ルフアライメント性能が 必須）やボイド（図 10 参照）など解決しなければいけない 課題も残されており, 解決に向けて研究開発が継続されて いる。

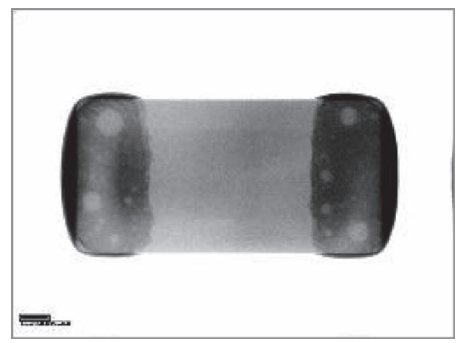

図 10.ボイド観察結果

\section{6. おわりに}

今回紹介した 3 種類の部品内蔵基板向けのはんだペース 卜技術は，まだ未熟な点が残っているものの，それぞれ非 常にユニークな特徵を持っているだけに，今後さらにブ ラッシュアップされることで部品内藏基板分野以外にも貢 献できそうな技術と思われる。また，これら技術を融合し た材料も期待でき，新たな接合材料技術が生み出される日 も近そうである。

(2014.5.26- 受理)

\section{文献}

1) 青木 仁: “内藏受動部品の動向と今後の展望,”エレクト ロニクス実装学会誌, Vol. 15, No. 7, pp. 522-525, 2012

2) 加藤力弥：“エレクトロニクス実装学会春季講演大会,” 2016

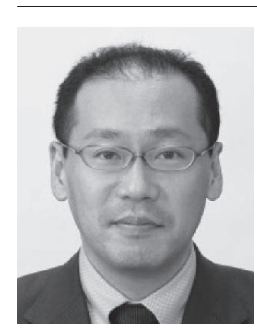

著者紹介

日渡逸人（ひわたし はやと）

1999 年 龍谷大学大学院理工学研究科物質化学尃 攻修士課程修了後, 千住金属工業（株）に入社, 開発・技術部に所属し SMT 用はんだペースト 微小チップ部品用はんだペースト，ハロゲンフ リーペースト, マイクロボールアタッチ用フラッ クス開発に従事，開発営業を経て，現在に至る。 